(C) 2002 The Chemical Society of Japan

——般 論 文——

\title{
ディスク型固相抽出 GC/MS 法による大気環境中および 環境水中のフタル酸エステル類の分析
}

(2001 年 8 月 23 日受理)

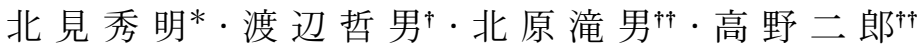

\begin{abstract}
本研究では, 外因性内分泌攪乱化学物質と疑われている 9 種類のフタル酸エステル類に着目し, デ ィスク型固相抽出法を用いて，その分析法の検討を行った．その際，排水基準に定められている揮発性 有機化合物 11 種類に含まれていないアセトンを抽出溶媒として用いることに着目し，その有効性につ いて調べた。その結果，アセトンで抽出しへキサンに転溶する方法(アセトン/ヘキサン転溶法)は，排 水基準項目に定められているジクロロメタンを使用しないで済むことから，実験室環境のジクロロメタ ンの混入を気にせずに前処理を行うことができる上に，回収率および变動係数の面でも優れていること から，かなり有効な抽出方法の一つであることがわかった．

実試料の定量結果は，河川水，降雨，環境大気すべてにおいて，フタル酸ビス (2-エチルヘキシル) がほかのフタル酸エステルに比べて $1-2 \mu \mathrm{g} / \mathrm{L}$ 以上と比較的高い濃度で検出された。また，全体的に はフタル酸エステル類 9 種類は河川水に存在する割合が高く，次いで環境大気，降雨となった．濃度 的には約 $0.05-3 \mathrm{ppb}$ 程度で環境中に存在していることが確認できた。
\end{abstract}

\section{1 緒訔}

我々人類は利便性を求め, 数多くの化学物質を合成してきた. そのため生活は豊かになり，化学物質は我々の日常生活の中で不 可欠なものとなっている.

しかし，その一方で，それら化学物質は我々に害を及ぼし，人 類の存続さえも脅かす抢それがあることが，1962 年に科学的 データに基づいて報告された1)。さらに，1996 年には外因性内 分泌攪乱化学物質による環境污染問題が深刻化していることも指 摘されている2).

近年, 生物の内分泌作用を攪乱する化学物質である外因性内分 泌攪乱化学物質 (Endocrine-Disrupting Chemicals : EDCs) を “環境ホルモン”と別称し，その生物への影響が大きな社会問題 となっている．これらは，特に生物の生殖抢よび甲状腺の内分泌 系に攪乱作用を示すといわれている3)-5)，その中で，主にプラス チックの可塑剤として用いられているフタル酸エステル類も環境 ホルモンと疑われ，その生体影響等が注目されており ${ }^{677)}$, 容器 包装等からの溶出が問題となっている. また, これらフタル酸エ ステル類は比較的難揮発性の化合物ではあるが，一部気化するた め, 河川水等の環境水だけではなく, 大気中の濃度も極めて低い

株式会社総合環境分析， 226-0003 横浜市緑区鴨居 1-13 $-2$

†東海大学教養学部人間環境学科自然環境課程, 259-1292 平塚市北金目 1117

†† 東海大学理学部化学科, 259-1292 平塚市北金目 1117
濃度レベルまで効率的に定量することが求められている．これは 生物の摂取量および生体影響をは握する上でも重要なことと思わ れる.

1998 年 5 月に我が国の環境庁 (現環境省)が環境ホルモンに対 する方針を定めた SPEED’98 には，67 物質(群)を環境ホルモン として取り上げているが，その中には 8 種類のフタル酸エステ 儿類が上がって抢り，それらの対応策について報告している8). それを受けて，この環境庁の分析方法を追試した結果についても 報告されている ${ }^{9)}$ また，これらフタル酸エステル類の分析方法 に関しては，以前から検討されており10)，ディスク型固相によ る前処理に関してもさまざま検討されているが1112)，これまで 抽出溶媒の最適化抢よび前処理による他の分析項目への影響を考 虑したものが見当たらない。

従来検討されてきた固相は，プラスチック製のカラムにオクタ デシル基を結合させたシリカゲル粒子，またはスチレンジビニル ベンゼン共重合体粒子を詰めたカートリッジ型固相である.

一方，米国の EPA Method ${ }^{13)-15)}$ に採用されているディスク型 固相はポリテトラフルオロエチレンの網目状繊維に固相粒子を保 持させたもので, ディスク型はカラム型と違い表面積が大きく, 試料の汇過速度が速く, 污染物質の保持力も優れている.

そこで本研究では, それら 8 種類を含む外因性内分泌攪乱化 学物質と疑われているフタル酸エステル類 9 種類に着目し，デ ィスク型固相抽出法を用いて, 大気環境中および環境水中の分析 法の検討を行った。このディスク型固相抽出法では, EPA Method 525.213) によると，酢酸エチルおよびジクロロメタンで 
抽出し, 酢酸エチルに転溶し, 測定となっており, EPA Method 8061 ${ }^{14)}$ 抢よび EPA Method 3535A ${ }^{15)}$ によると，アセトニトリ ルで抽出し, ヘキサンに転溶し, 測定となっている. そこで, そ れらの結果を示すとともに，さらなる回収率および精度の向上の ため, 抽出溶媒の種類を検討した. 固相抽出にはジクロロメタン がよく用いられるが，ジクロロメタンは排水基準項目に含まれる ため, これを大量に使用することは, 同一実験室内で行われるジ クロロメタンの測定に大きな䛊差をもたらす．このため本研究で は，このような抢それのない抽出溶媒としてアセトンに着目し， その有効性に関する検討を行ったので，その結果について報告す る.

\section{2 実 験}

\section{1 試 薬}

各フタル酸エステル類 (フタル酸ジエチル $(\mathrm{DEP})$, フタル酸ジ プロピル $(\mathrm{DPrP})$, フタル酸ジイソブチル $(\mathrm{D}-\mathrm{iso}-\mathrm{BP})$, フタル酸 ジブチル $(\mathrm{DBP})$, フタル酸ジペンチル $(\mathrm{DPeP})$, フタル酸ジへキ シル $(\mathrm{DHP})$, フタル酸ベンジルブチル $(\mathrm{BBP})$, フタル酸ジシク ロヘキシル $(\mathrm{DCHP})$, フタル酸ビス (2-エチルヘキシル) $(\mathrm{BEHP})$ ), フタル酸ジチル $-d_{4}\left(\mathrm{DEP}-d_{4}\right)$ (サロゲート物質 : Surrogate Standard), クリセン $-d_{12}$ (内標準物質 : Internal Standard）は関東化学秼製の環境分析用を使用した。アセトン, メタ ノール, ジクロロメタン, 酢酸エチル, アセトニトリルは, 和光 純薬工業秼製の残留農薬 2000 倍試験用を使用した。その他の試 薬は，和光純薬工業侏製の試薬特級を使用した。 なた，分析に使 用した水は蒸留水を使用した，この蒸留水は煮沸し，VOCを十 分に除去し，プラスチック製品等に接触しないようにしたものを 使用した。

フタル酸エステル類 9 種類の標準液の調製は, アセトンで抽 出しへキサンに転溶する万法(アセトン/ヘキサン転溶法)で前処 理を行った場合はへキサンを溶媒として，1000 mg/L の標準原 液を調製した。この標準原液をへキサンを用いて適宜混合希釈 し, 混合標準液を調製し実験に使用した。つまり，ディスク型固 相抽出で最終的にフタル酸エステル類を溶かした溶媒と同じ種類 の溶媒で標準液を調製し, 溶媒の差による GC/MS 測定時の変 動が起こらないようにして実験を行った.

\section{2 装置および条件}

GC/MS に関する測定装置および測定条件は Table 1 に示した とおりである. GC/MS によるフタル酸エステル類 9 種類の定量 には，スキャン測定の後に選択イオン検出法 (Selected Ion

Table 1 Analytical conditions by nine phthalic esters

\begin{tabular}{ll}
\hline GC/MS & GC-17A, GCMS-QP5050 (Shimadzu Co.) \\
GC column & CP-SIL 8CB-MS (CHROMPACK), \\
& $30 \mathrm{~m} \times 0.25 \mathrm{~mm}$ id $\times 0.25 \mu \mathrm{m}$ film thickness \\
Carrier gas & $\mathrm{Helium}, 50 \mathrm{~mL} / \mathrm{min}$ \\
Column temp. & $50{ }^{\circ} \mathrm{C}, 5 \mathrm{~min}-\left(10{ }^{\circ} \mathrm{C} / \mathrm{min}\right)-180{ }^{\circ} \mathrm{C}$, \\
& $7 \mathrm{~min}-\left(15{ }^{\circ} \mathrm{C} / \mathrm{min}\right)-250{ }^{\circ} \mathrm{C}, 6 \mathrm{~min}$ \\
Injection & $\mathrm{Splitless,} 1 \mu \mathrm{L}$ \\
Injection temp. & $250{ }^{\circ} \mathrm{C}$ \\
Interface temp. & $280{ }^{\circ} \mathrm{C}$ \\
Ionization & $\mathrm{EI}, 70 \mathrm{eV}$ \\
\hline
\end{tabular}

Monitoring : SIM) を用いて行い, 内標準法により検量線を作成 し定量した。ここで，内標準物質および安定同位体標識標準品 (サロゲート物質)の最終溶液濃度は $0.5 \mathrm{mg} / \mathrm{L}$ とした．ディスク 型固相の漏出 (ブレイクスルー) を確認する際に使用した TOC 計 は，島津製作所製の TOC-5000A である.

今回の実験で抽出に用いた固相は, 住友 $3 \mathrm{M}$ 製のオクタデシ ル基を結合させたポリマー系エムポアTM抽出ディスク $\mathrm{C} 18$ (厚 $0.5 \mathrm{~mm}$, 径 $47 \mathrm{~mm}$ ) である. ディスク型固相を用いて, アセ卜 ン/ヘキサン転溶法による抽出操作をそれぞれ Fig. 1-3 に示 す.ここで, Fig. 1 は水質 (河川水, 降雨)の場合, Fig. 2 (超音 波抽出による方法) 抢よび Fig. 3(自然通液による抽出方法) は環 境大気の場合である。 また, 環境大気の捕集および抽出にはディ スクホルダーおよびマニホールド(住友 $3 \mathrm{M}$ 製)を使用した。こ こで, 環境大気の捕集において使用したポンプおよび積算流量計 は, 柴田科学製の AIR PUMP SIP-32L, シナガワ製の DRY TEST GAS METER DC-2A を使用した。 また, 実試料による 添加回収試験においては, SS(懸濁物質 : Suspended Solid)の影 響を取り除くために，SS 測定用のガラス緎維濾紙 (Grass Membrane Filter:GMF, GS-25, ADVANTEC 社製)を使用した。 た,これらすべての器具に関しては, アセトンで洗浄後, 乾燥し 測定等に使用した.

\section{3 実試料}

今回実験に使用した実試料は，東京都町田市境川で 2000 年 6 月 5 日に採取した河川水, 制総合環境分析で 2000 年 6 月 6 日に 採取した環境大気， 2000 年 6 月 8 日に採取した初期降雨 $10 \mathrm{~mm}$ (無沪過一括採取)である.ここで, 河川水の成分分析した結果を Table 2 に, 降雨の成分分析を行った結果を Table 3 に示す.こ れら実試料の成分分析は, 公定法16)17)に基づいて行った.

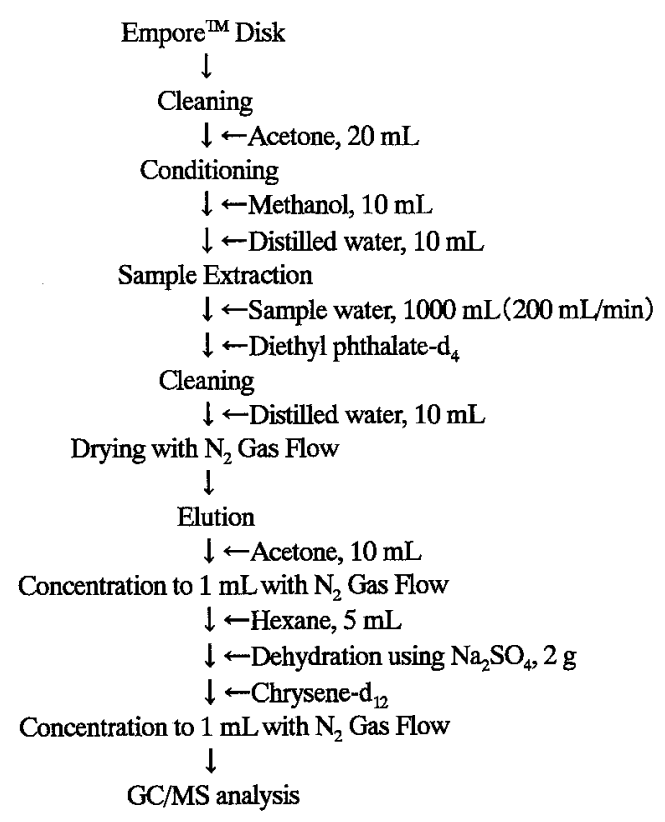

Fig. 1 Typical procedure for nine phthalic esters analysis of environmental water. 


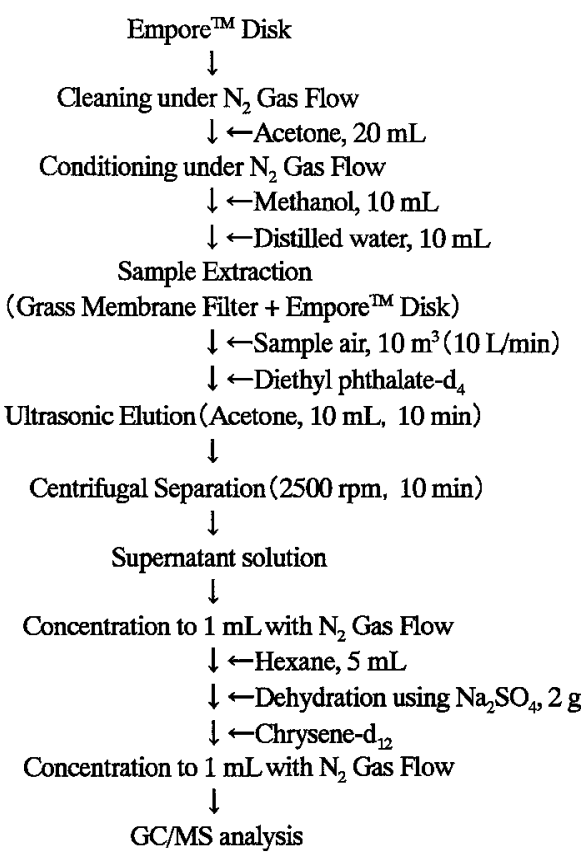

Fig. 2 Typical procedure for nine phthalic esters analysis of atmosphere by ultrasonic elution.

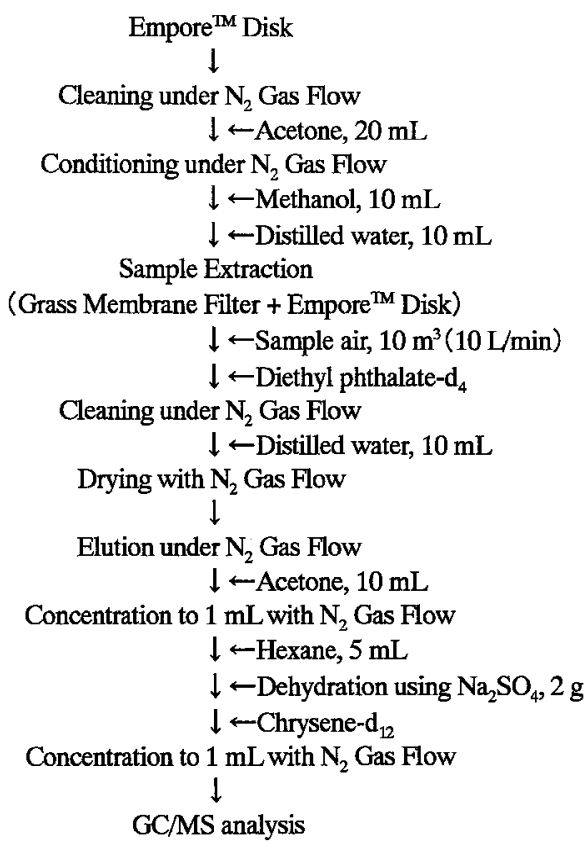

Fig. 3 Typical procedure for nine phthalic esters analysis of atmosphere by natural elution.

\section{3 実験結果および考察}

\section{1 フタル酸エステル類 9 種類混合標準溶液の $\mathrm{GC} / \mathrm{MS}$ 測定}

まず, Fig. 4 に環境ホルモンと疑われているフタル酸エステル 類 9 種類を，それぞれへキサンで溶かした標準溶液 $2 \mathrm{mg} / \mathrm{L}$ にお けるスキャン測定を行ったときの全イオンクロマト（Total Ion
Table 2 Characteristic of the river water

\begin{tabular}{cc}
\hline Items & Concentration $/ \mathrm{mg} \mathrm{L}^{-1}$ \\
\hline $\mathrm{pH}$ & 7.3 \\
$\mathrm{BOD}$ & 1.8 \\
$\mathrm{COD}$ & 4.9 \\
$\mathrm{SS}$ & 4 \\
$\mathrm{~T}-\mathrm{N}$ & 4.64 \\
$\mathrm{~T}-\mathrm{P}$ & 0.305 \\
\hline
\end{tabular}

Table 3 Characteristic of the rain water

\begin{tabular}{cc}
\hline Items & Concentration $/ \mathrm{mg} \mathrm{L}^{-1}$ \\
\hline $\mathrm{pH}$ & 6.8 \\
$\mathrm{SS}$ & $<1$ \\
$\mathrm{EC}{ }^{\mathrm{a}}$ & 15.1 \\
$\mathrm{Ca}^{2+}$ & 0.12 \\
$\mathrm{Mg}^{2+}$ & 0.08 \\
$\mathrm{~K}^{+}$ & 0.02 \\
$\mathrm{Na}^{+}$ & 0.37 \\
$\mathrm{NH}_{4}{ }^{+}$ & 0.49 \\
$\mathrm{Cl}^{-}$ & 0.32 \\
$\mathrm{NO}_{3}{ }^{-}$ & 1.9 \\
$\mathrm{SO}_{4}{ }^{2-}$ & 1.1
\end{tabular}

a) Concentration $/ \mu \mathrm{S} \mathrm{cm}^{-1}$.

Chromatogram : TIC) を示す。ここで， 1 がフタル酸ジエチル (DEP), 2 がフタル酸ジプロピル (DPP), 3 がフタル酸ジイソブ チル (D-iso-BP ), 4 がフタル酸ジブチル $(\mathrm{DBP}), 5$ がフタル酸ジ ペンチル $(\mathrm{DPeP}), 6$ がフタル酸ジヘキシル $(\mathrm{DHP}), 7$ がフタル酸 ベンジルブチル $(\mathrm{BBP}), 8$ がフタル酸シシクロヘキシル $(\mathrm{DCHP})$, 9 がフタル酸ビス (2-エチルヘキシル) (BEHP)である.

この標準溶液を測定したところ，本測定条件では，SIM 測定 で全 9 種類 $2 \mathrm{mg} / \mathrm{L}-0.2 \mu \mathrm{g} / \mathrm{L}$ の範囲に抢いて検量線の直線性(相 関係数 $r=0.999-0.981)$ が得られ， $0.5 \mathrm{mg} / \mathrm{L}$ の標準溶液の測定 において 5 回繰り返し測定した結果, 各物質ともに変動係数が 5 $\%$ 以下であった。 また，本測定条件で連続測定する際に，GC オーブンを $250{ }^{\circ} \mathrm{C}$ で 6 分以上保つことにより，カラム内に前検 体の影響が出ないようにすることが可能であった.

ここで, 測定に際し, 標準溶液の溶媒に関する検討を行った. 各フタル酸エステル類 9 種類をへキサン, アセトン, 酢酸エチ ル，それぞれに $0.5 \mathrm{mg} / \mathrm{L}$ になるように溶かした標準溶液 100 $\mathrm{mL}$ に, 蒸留水 $1 \mathrm{~mL}$ を添加し, 無水硫酸ナトリウム $10 \mathrm{~g}$ で脱水 した後，その溶液を本測定条件で 10 回連続に測定した DEP の 結果を Fig. 5 に示す。この図から明らかなように、へキサンが 最も安定であることがわかる。 また，その他の各フタル酸エステ 儿類も同様の結果であった。これは，他の溶媒に比べ，へキサン の脱水が最も効率的に行われたことを示しており，測定の際にキ ヤピラリーカラムに対して水分による不安定さおよび劣化を誘発 しなかったことによると考えられる.

\section{2 蒸留水による添加回収試験}

次に，蒸留水を用いて成分の一斉前処理である添加回収試験を 行った.この試験は，9種類のフタル酸エステル類をそれぞれの 検出濃度が $0.2 \mu \mathrm{g} / \mathrm{L}$ になるように添加し，ただちに回収すると いったものである(前処理を含めた繰り返し測定回数 5 回 : $n=$ 


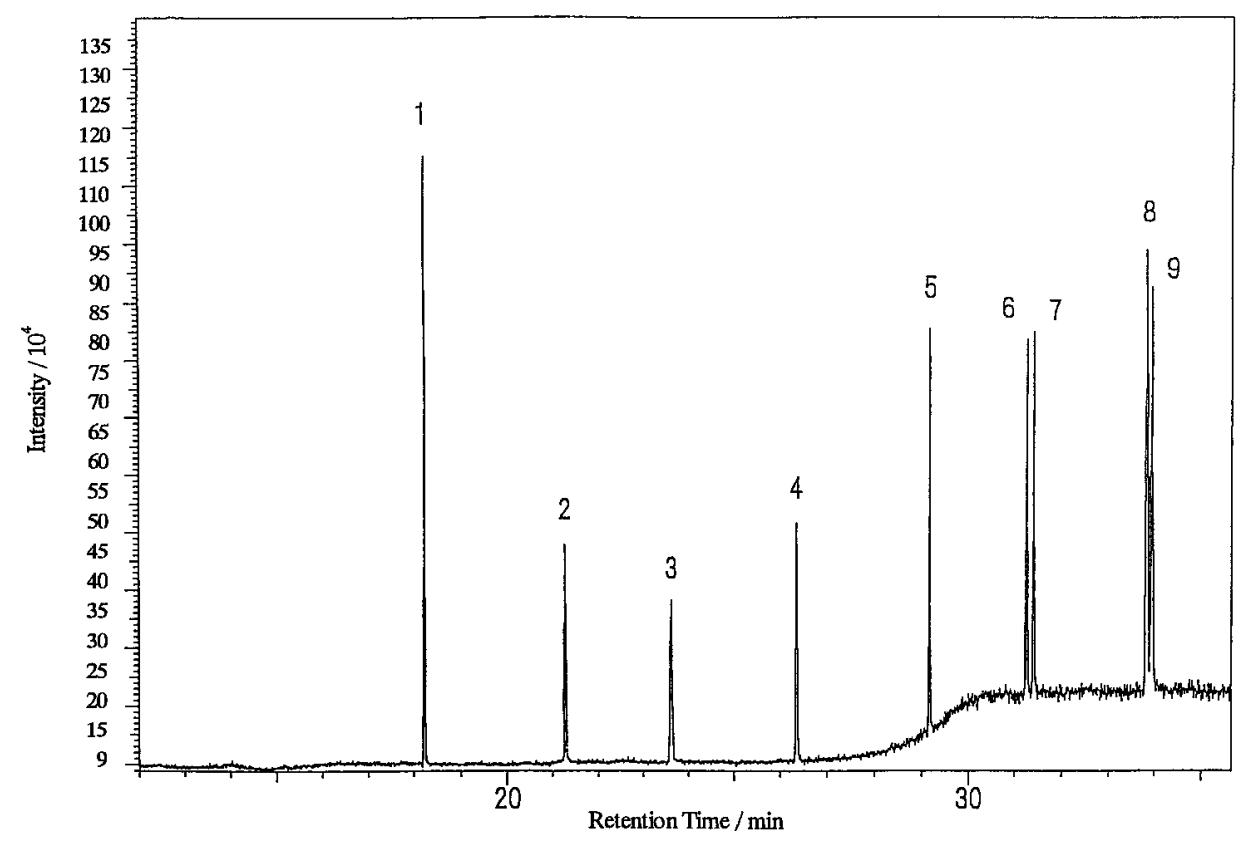

Fig. 4 Total ion chromatogram of nine phthalic esters by GC/MS with EI. 1 : DEP; 2 : DPrP; 3 : D-iso-BP; 4 : DBP; 5 : DPeP; 6 : DHP; 7 : BBP; 8 : DCHP; 9 : BEHP.

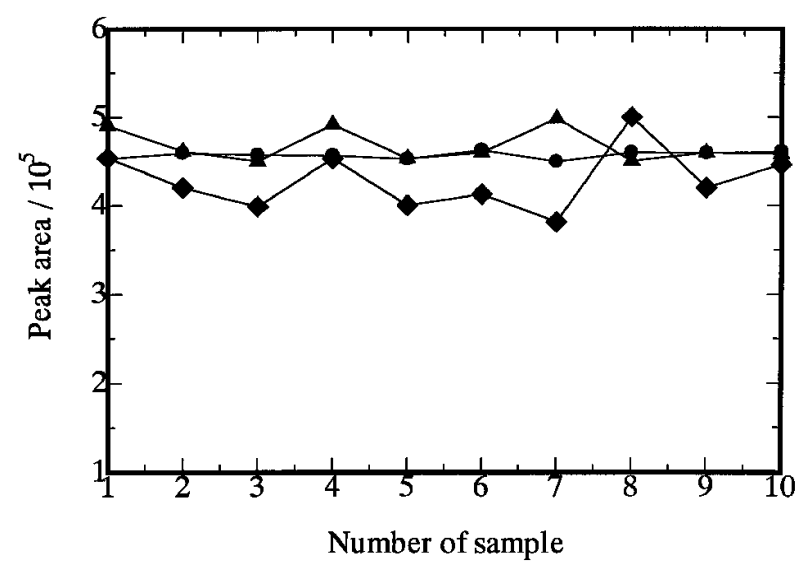

Fig. 5 Measuring results for standard samples of different solvent in DEP, $0.5 \mathrm{mg} / \mathrm{L}$.

: Hexane, $\boldsymbol{\nabla}$ : acetone, $\boldsymbol{\Delta}$ : ethyl acetate.

5). その結果を Table 4 に示す.

ここで, Fig. 1 の通水のところで, フタル酸エステル類 9 種類 の初期濃度がそれぞれ $2 \mathrm{mg} / \mathrm{L}$ の場合において, 流速 $200 \mathrm{~mL} /$ $\min$ では流出水の TOC 值が $0.1 \mathrm{mg} / \mathrm{L}$ 以下であったこと, 抢よ びサロゲート物質の回收率からみても特に損失がなかったことか ら漏出は起こっていないと考えられる.

EPA Method 525.213) では抽出溶媒にジクロロメタンおよび酢 酸エチルを使用し，EPA Method 8061 ${ }^{14)}$ 抢よび EPA Method 3535A ${ }^{15)}$ では抽出溶媒にアセトニトリルを使用するが， Table 4 から明らかなように，それらをアセトンのみ，またはへキサンの みで代用した場合は, 変動係数も大きく回収率も悪くなっている ことがわかる．これは，3.1の結果からもいえるが，アセトンは 親水性であるため, 無水硫酸ナトリウムのみでは脱水が不十分に
なってしまうことによると思われる。 また、へキサンにおいて は, 回收率が他の系に比べ低いため, フタル酸エステル類の抽出 には適さないと思われる，そこで，このアセトンの欠点を解消す るために, アセトンで抽出した後, ヘキサンに転容する操作を加 えた．このことにより, 変動係数も低くなり回収率も向上し, ほ ぼジクロロメタンおよび酢酸エチルと同様の結果, つまり, 変動 係数 $6 \%$ 以内かつ回収率約 $100 \%$ が得られた。また, EPA Method 8061'14) および EPA Method 3535A ${ }^{15)}$ で使用されている アセトニトリルは回収率抢よび変動係数に関して, EPA Method 525.213) やアセトン/ヘキサン転容法よりも劣っていた.

\section{3 標準試料ガスによる添加回収試験}

次に, 標準試料ガスを用いて成分の一斉前処理である添加回収 試験を行った。この試験は, エムポアディスクに 9 種類のフタ ル酸エステル類をそれぞれの検出濃度が $0.2 \mu \mathrm{g} / \mathrm{L}$ になるように 標準溶液を添加し，その直後に窒素ガスを $10 \mathrm{~L} / \mathrm{min}$ で $10 \mathrm{~m}^{3}$ デ ィスクに通し，ただちに回収するといったものである $(n=5)$. ここで, まず抽出方法として Fig. 2 と Fig. 3 とに示した二通り を検討を行った．その結果を Table 5 に示す．この表から明らか なように，超音波抽出による方法では，変動係数が $7.2-9.7 \%$ と 大きく, 回収率も自然抽出による方法に比べて若干ではあるが低 い.これは, 超音波抽出による方法の場合, 超音波の影響により ディスクから若干のポリマー成分の溶出があり, さらにそれを取 り除くために遠心分離を行うことから，ポリマー成分への再吸着 および遠心分離による損失等によると思われる，そこで，この結 果を踏まえて, Fig. 3 に示した自然通液による抽出方法を実試料 を含めて採用し，後の検討を行った．

次に, 抽出溶媒の違いによる变動係数および回収率の差につい て検討した結果を Table 6 に示す.この表から明らかなように, 抽出溶媒が酢酸エチル抢よびジクロロメタンの場合は変動係数お よび回収率，共に良好であることがわかる．またアセトンのみの 
Table 4 Recovery of nine phthalic esters in distilled water $(n=5)$

\begin{tabular}{|c|c|c|c|c|c|}
\hline \multirow[b]{2}{*}{ Phthalic ester } & \multicolumn{5}{|c|}{ Mean $[\%](\mathrm{CV}[\%]$ : Coefficient of variation $)$} \\
\hline & Acetonitrile & $\begin{array}{c}\text { Ethyl acetate } / \\
\text { Dichloromethane }=1 / 1\end{array}$ & $\begin{array}{l}\text { Capital acetone } \\
\text { and hexane }\end{array}$ & Acetone & Hexane \\
\hline Diethyl phthalate (DEP) & $88.3(4.3)$ & $95.0(3.6)$ & $96.2(3.8)$ & $84.6(9.1)$ & $81.5(6.9)$ \\
\hline Dipropyl phthalate (DPrP) & $86.7(5.2)$ & $94.2(4.3)$ & $98.5(4.1)$ & $83.8(8.6)$ & $85.1(5.7)$ \\
\hline Diisobutyl phthalate (D-iso-BP) & $86.4(6.3)$ & $95.8(5.5)$ & $97.2(5.3)$ & $78.9(8.8)$ & $83.4(6.9)$ \\
\hline Dibutyl phthalate (DBP) & $90.7(6.7)$ & $105.1(5.9)$ & $99.8(5.1)$ & $87.4(9.8)$ & $90.3(6.8)$ \\
\hline Dipentyl phthalate (DPeP) & $85.4(6.1)$ & $101.3(5.0)$ & $101.6(4.9)$ & $71.8(9.3)$ & $77.8(7.1)$ \\
\hline Dihexyl phthalate (DHP) & $90.5(6.8)$ & $102.5(5.3)$ & $98.9(5.2)$ & $70.9(9.9)$ & $78.5(6.8)$ \\
\hline Benzyl butyl phthalate (BBP) & $91.2(5.5)$ & $97.8(4.8)$ & $98.4(5.1)$ & $85.3(8.3)$ & $81.4(6.9)$ \\
\hline Dicyclohexyl phthalate (DCHP) & $86.1(6.9)$ & $102.1(5.4)$ & $101.3(5.7)$ & $75.3(8.4)$ & $82.4(7.7)$ \\
\hline Bis (2-ethylhexyl) phthalate (BEHP) & $92.4(6.5)$ & $110.5(5.6)$ & $103.1(5.9)$ & $111.5(9.9)$ & $89.1(7.2)$ \\
\hline Diethyl phthalate $-d_{4}\left(\mathrm{DEP}-d_{4}\right)$ & $94.3(4.1)$ & $98.9(3.4)$ & $99.5(3.1)$ & $90.5(6.9)$ & $88.6(5.7)$ \\
\hline
\end{tabular}

Table 5 Comparison of recovery of nine phthalic esters ${ }^{\text {a) }}$ between natural elution and ultrasonic elution $(n=5)$

\begin{tabular}{lcc}
\hline \multirow{2}{*}{ Phthalic ester } & Mean [\%] $(\mathrm{CV}[\%]$ : Coefficient of variation) \\
\cline { 2 - 3 } & Natural elution & Ultrasonic elution \\
\hline Diethyl phthalate (DEP) & $96.2(4.9)$ & $88.1(9.7)$ \\
Dipropyl phthalate (DPrP) & $98.5(5.1)$ & $90.2(7.9)$ \\
Diisobutyl phthalate (D-iso-BP) & $97.6(5.8)$ & $91.1(9.1)$ \\
Dibutyl phthalate (DBP) & $98.8(5.7)$ & $89.8(9.2)$ \\
Dipentyl phthalate (DPeP) & $99.6(4.8)$ & $91.2(8.5)$ \\
Dihexyl phthalate (DHP) & $95.9(5.6)$ & $90.1(8.5)$ \\
Benzyl butyl phthalate (BBP) & $98.1(5.1)$ & $92.8(9.3)$ \\
Dicyclohexyl phthalate (DCHP) & $96.3(5.2)$ & $89.3(7.8)$ \\
Bis $(2-$ ethylhexyl) phthalate $($ DEHP) & $99.6(5.7)$ & $93.4(8.5)$ \\
Diethyl phthalate- $d_{4}\left(\right.$ DEP- $\left.d_{4}\right)$ & $99.5(3.4)$ & $95.9(7.2)$ \\
\hline
\end{tabular}

a) Standard solution of phthalic esters were added on the filter and $10 \mathrm{~m}^{3}$ of $\mathrm{N}_{2}$ gas was passed through the filter.

Table 6 Comparison of recovery of nine phthalic esters with various organic solvents by natural elution $(n=5)$

\begin{tabular}{|c|c|c|c|c|c|}
\hline \multirow{2}{*}{ Phthalic ester } & \multicolumn{5}{|c|}{ Mean [\%] (CV [\%]: Coefficient of variation) } \\
\hline & Acetonitrile & $\begin{array}{c}\text { Ethyl acetate/ } \\
\text { Dichloromethane }=1 / 1\end{array}$ & $\begin{array}{l}\text { Capital acetone } \\
\text { and hexane }\end{array}$ & Acetone & Hexane \\
\hline Diethyl phthalate (DEP) & $88.9(6.1)$ & $90.2(4.5)$ & $96.2(4.9)$ & $90.1(7.3)$ & $88.4(3.9)$ \\
\hline Dipropyl phthalate (DPrP) & $88.5(6.9)$ & $93.1(4.8)$ & $98.5(5.1)$ & $85.1(8.8)$ & $83.9(4.5)$ \\
\hline Diisobutyl phthalate (D-iso-BP) & $84.3(6.4)$ & $97.7(5.3)$ & $97.6(5.8)$ & $79.4(7.8)$ & $80.5(5.1)$ \\
\hline Dibutyl phthalate (DBP) & $93.5(6.0)$ & $95.3(6.1)$ & $98.8(5.7)$ & $77.1(8.9)$ & $89.4(5.4)$ \\
\hline Dipentyl phthalate (DPeP) & $90.4(6.8)$ & $93.8(5.0)$ & $99.6(4.8)$ & $70.8(9.1)$ & $78.6(4.3)$ \\
\hline Dihexyl phthalate (DHP) & $93.2(6.5)$ & $102.5(5.3)$ & $95.9(5.6)$ & $72.7(8.5)$ & $80.4(5.5)$ \\
\hline Benzyl butyl phthalate (BBP) & $91.2(6.2)$ & $97.8(4.8)$ & $98.1(5.1)$ & $79.8(8.9)$ & $82.9(5.1)$ \\
\hline Dicyclohexyl phthalate (DCHP) & $88.1(6.6)$ & $98.1(5.4)$ & $96.3(5.2)$ & $81.4(8.1)$ & $87.9(5.4)$ \\
\hline Bis (2-ethylhexyl) phthalate (DEHP) & $90.3(6.9)$ & $103.5(5.4)$ & $99.6(5.7)$ & $115.7(9.1)$ & $98.3(5.5)$ \\
\hline Diethyl phthalate $-d_{4}\left(\mathrm{DEP}-d_{4}\right)$ & $95.9(5.3)$ & $98.4(3.8)$ & $99.5(3.4)$ & $91.4(6.9)$ & $94.7(3.9)$ \\
\hline
\end{tabular}

場合は，回收率は高いが変動係数が大きい。さらに，へキサンの みの場合は, 変動係数は低く回収率も低い。しかし, アセトン/ ヘキサン転溶法においては，酢酸エチルおよびジクロロメタン同 様の低い変動係数抢よび高い回收率を示した。 また，アセトニト リルの場合に拈いては，3.2 同様，EPA Method 525.213) やアセ トン/ヘキサン転溶法よりも劣っていることが確認できた.

\section{4 実試料(河川水, 降雨, 環境大気)の定量}

Fig. 1 による万法で河川水抢よび降雨の実試料を定量した結果
を Table 7 および Table 8 に示す．また，Fig. 3 による方法で環 境大気の実試料を定量した結果を Table 9 に示す。まず，Table 2 および Table 3 に示した成分分析の結果から，今回使用した実 試料はそれほど污染されていないものであるが，SSの濃度が河 川水は $4 \mathrm{mg} / \mathrm{L}$ で降水は $<1 \mathrm{mg} / \mathrm{L}$ と差がある. Table 7, Table 8 および Table 9 に示すように, 河川水, 降雨, 環境大気すべて から, DPrP, DPeP, DHP, DCHP が検出されなかった。 また， 特に Table 7 からわかるように, 河川水に拈いては, SS をガラ 
Table 7 Concentration of nine phthalic esters in the river water $(n=5)$

\begin{tabular}{lcc}
\hline \multirow{2}{*}{ Phthalic ester } & \multicolumn{2}{c}{ Concentration $/ \mu \mathrm{g} \mathrm{L}^{-1}(\mathrm{CV}[\%]$ : Coefficient of variation) } \\
\cline { 2 - 3 } & $\mathrm{GMF}+$ Capital acetone and hexane & Capital acetone and hexane \\
\hline Diethyl phthalate (DEP) & $0.58(6.8)$ & $0.65(7.6)$ \\
Dipropyl phthalate (DPrP) & $\mathrm{ND}$ & $\mathrm{ND}$ \\
Diisobutyl phthalate (D-iso-BP) & $0.14(6.8)$ & $0.29(7.8)$ \\
Dibutyl phthalate (DBP) & $0.98(6.9)$ & $1.52(8.4)$ \\
Dipentyl phthalate (DPeP) & $\mathrm{ND}$ & $\mathrm{ND}$ \\
Dihexyl phthalate (DHP) & $\mathrm{ND}$ & $\mathrm{ND}$ \\
Benzyl butyl phthalate (BBP) & $0.62(6.6)$ & $1.38(7.4)$ \\
Dicyclohexyl phthalate (DCHP) & $\mathrm{ND}$ & $\mathrm{ND}$ \\
Bis (2-ethylhexyl) phthalate (DEHP) & $2.13(6.9)$ & $2.84(8.1)$ \\
\hline
\end{tabular}

a) ND: Not detected.

Table 8 Concentration of nine phthalic esters in the rain water $(n=5)$

\begin{tabular}{lcc}
\hline \multirow{2}{*}{ Phthalic ester } & \multicolumn{2}{c}{ Concentration $/ \mu \mathrm{g} \mathrm{L} \mathrm{L}^{-1}$ (CV [\%]: Coefficient of variation) } \\
\cline { 2 - 3 } & $\mathrm{GMF}+$ Capital acetone and hexane & Capital acetone and hexane \\
\hline Diethyl phthalate (DEP) & $0.15(6.4)$ & $0.21(5.3)$ \\
Dipropyl phthalate (DPrP) & $\mathrm{ND}$ & $\mathrm{ND}$ \\
Diisobutyl phthalate (D-iso-BP) & $0.05(5.6)$ & $0.08(5.4)$ \\
Dibutyl phthalate (DBP) & $0.69(7.1)$ & $0.97(6.8)$ \\
Dipentyl phthalate (DPeP) & $\mathrm{ND}$ & $\mathrm{ND}$ \\
Dihexyl phthalate (DHP) & $\mathrm{ND}$ & $\mathrm{ND}$ \\
Benzyl butyl phthalate (BBP) & $0.51(5.9)$ & $0.68(6.1)$ \\
Dicyclohexyl phthalate (DCHP) & $\mathrm{ND}$ & $\mathrm{ND}$ \\
Bis (2-ethylhexyl) phthalate (DEHP) & $1.05(5.5)$ & $1.37(6.4)$ \\
\hline
\end{tabular}

a) ND: Not detected.

Table 9 Concentration of nine phthalic esters in the atmosphere $(n=5)$

\begin{tabular}{lcc}
\hline \multirow{2}{*}{ Phthalic ester } & \multicolumn{2}{c}{ Concentration $/ \mu \mathrm{g} \mathrm{L}{ }^{-1}(\mathrm{CV}[\%]$ : Coefficient of variation) } \\
\cline { 2 - 3 } & $\mathrm{GMF}+$ Capital acetone and hexane & Capital acetone and hexane \\
\hline Diethyl phthalate (DEP) & $0.31(7.1)$ & $0.45(6.6)$ \\
Dipropyl phthalate (DPrP) & $\mathrm{ND}$ & $\mathrm{ND}$ \\
Diisobutyl phthalate (D-iso-BP) & $0.09(6.9)$ & $0.18(7.2)$ \\
Dibutyl phthalate (DBP) & $1.03(7.5)$ & $1.94(7.9)$ \\
Dipentyl phthalate (DPeP) & $\mathrm{ND}$ & $\mathrm{ND}$ \\
Dihexyl phthalate (DHP) & $\mathrm{ND}$ & $\mathrm{ND}$ \\
Benzyl butyl phthalate (BBP) & $0.83(6.4)$ & $1.05(7.8)$ \\
Dicyclohexyl phthalate (DCHP) & $\mathrm{ND}$ & $\mathrm{ND}$ \\
Bis (2-ethylhexyl) phthalate (DEHP) & $1.96(7.1)$ & $2.21(7.3)$ \\
\hline
\end{tabular}

a) ND: Not detected.

ス繊維沪紙で取り除いた方が，変動係数が低くなったことから， SS による測定上の不安定さが出ることが実試料の定量から確認 できた.これらの結果から, 環境中のフタル酸エステル類として は，河川水，降雨，環境大気すべてに扔いて，DEHP が $1-2 \mu \mathrm{g}$ /L 以上とほかのフタル酸エステルに比べて比較的高濃度に存在 することがわかった。 また，フタル酸エステル類は 9 種類と も, 河川水での存在比が多く, 次いで環境大気, 降雨となった. 濃度的には約 $0.05-3 \mathrm{ppb}$ 程度で環境中に存在していることが確 認できた。

\section{4 結 論}

本研究では, 外因性内分泌攪乱化学物質と疑われているフタル 酸エステル類 9 種類に着目し, ディスク型固相抽出法を用い て，その分析法の検討を行った．その際，排水基準項目（揮発性 有機化合物 11 種類)に含まれていないアセトンを抽出溶媒とし て用いることに着目し，その有効性について調べた。その結果， 共存物質の影響が少ない環境水および環境大気においては, アセ トン/ヘキサン転溶法は, 排水基準項目に含まれているジクロロ メタンを使用しないで済むことから，実験室環境のジクロロメタ 
ンによる混入(コンタミネーション)を気にせず前処理を行うこと ができるうえに, 回収率および変動係数の面でも優れていること から，有効な抽出方法の一つとなることを示した.

1) R. Carson, "Silent Spring”, New York, (1962).

2) T. Colborn, D. Dumanoski, J. P. Myers, "Our Stolen Future. Dutton", New York (1996).

3) T. Colborn, F. S. vom Saal, A. M. Soto, Environ. Health Perspect, 101, 378(1993).

4) T. Iguchi, Int. Rev. Cytol., 139, 1(1992).

5) T. Iguchi, H. A. Bern, Comments Toxicol, 5, 367 (1996).

6) S. Oishi, K. Hiraga, Toxicol. Appl. Pharmacol., 53, 35 (1980).

7) A. H. Catharine, H. Pirkko, G. P. Malcolm, P. S. John, Environ. Health Perspect, 105, 802 (1997)

8）環境庁, “外因性内分泌攪乱化学物質問題への環境庁の対 応方針について一環境ホルモン戦略計画 SPEED’98-”,
(1998).

9）木村義孝，小俣美郁子，望月あい，吉池恒久，環境と測 定技術，27，4，32(2000).

10) J. A. Glazer, G. D. Foerst, G. D. McKee, S. A. Quave, W L. Budde, Environ. Sci. Technol., 15, 1426 (1981).

11) M. E. Walsh, T. Ranney, J. Chromatogr. Sci., 36, 406 (1998).

12）斎藤育江，瀬戸 博，環境と測定技術， 27，9，64(2000).

13) US Environmental Protection Agency, EPA Method 525.2 (1994).

14) US Environmental Protection Agency, EPA Method 8061A (1996).

15) US Environmental Protection Agency, EPA Method $3535 \mathrm{~A}(2000)$.

16）日本規格協会，“工場排水試験方法 JIS K0102”，(1993）.

17）環境庁大気保全局，“酸性雨等調査マニュアル”，(1990).

\title{
Determination of Phthalic Esters in Atmospheric Environment and Environmental Water by GC/MS with Disk-format Solid Phase Extraction Method
}

\author{
Hideaki Kitami*, Tetsuo WATANABE ${ }^{\dagger}$, Takio KitaharA ${ }^{\dagger \dagger}$ and Jiro TAKANO ${ }^{\dagger \dagger}$ \\ Sougou Kankyou Bunseki Co., Ltd.; 1-13-2 Kamoi, Midori-ku, Yokohama-shi 226-0003 Japan \\ ${ }^{\dagger}$ Department of Resources and Environmental Science, School of Humanities and Culture, Tokai \\ University; 1117 Kitakaname, Hiratsuka-shi 259-1292 Japan \\ ${ }^{\dagger}$ Department of Chemistry, School of Science, Tokai University; 1117 Kitakaname, Hiratsuka-shi \\ 259-1292 Japan
}

A simple extraction method for the determination of the endocrine disrupting nine phthalic esters, by gas chromatography/mass spectrometry (GC/MS) with electron ionization (EI) is described. These compounds were adsorbed on a disk-format solid phase from river water, rain water and atmosphere. A capital acetone and hexane were investigated as solvents for elution of the nine phthalic esters adsorbed on the solid phase. As a result, a capital acetone and hexane turned out to be very effective and a high recovery (about 100\%) was obtained for nine phthalic esters in distilled water and reagent gas. This method was successfully applied to river water, rain water and atmosphere. 